\title{
EN ANTIKVAR AF FØRSTE SKUFFE MARTIN FRIDRICH ARENDT 1773-1823
}

\author{
$\mathrm{AF}$
}

\author{
Kirsten-Elizabeth Høgsbro
}

$\mathbf{I}^{\mathrm{d}}$ de indledende strofer af „Guldhornene " giver Adam Oehlenschläger udtryk for den ringeagt, han nærer over for dem, der i bøger, genstande og ruiner søger efter viden om de henfarene slægter. Men hvem var disse lærde, åndøse personer, der famlede om i blinde mellem efterladenskaber som i et benhus, og som ikke havde fornemmelse for oldtidens poesi og for det budskab, guldhornene bragte, et budskab som kun digteren kunne modtage og tolke?

Oehlenschläger havde, så vidt vides, da han skrev „Guldhornene“ ikke personlig kontakt med de etablerede oldgranskere i København, og han forblev livet igennem stort set fremmed over for den videnskabelige side af oldforskningen. Anden var for ham det vaesentlige, de materielle levn fra fortiden, det være sig monumenter eller genstande, interesserede ham ikke.' I et brev fra 16. juni 1800 til sin senere hustru Christiane Heger fortalte han om et besøg, han narmest „for en fejls skyld" sammen med en ven, der skulle rejse til Norge, havde aflagt på Kunstkammeret, men navner ikke noget om, at han havde lagt serlig marke til de to guldhorn ved den lejlighed. ${ }^{2}$ Det var først, da de blev stjålet, blev usynlige, at de blev synlige for digteren!

Imidlertid var der én oldgransker, som Oehlenschläger kendte, og som han har skildret i sine erindringer. Det var en af datidens „markvardige karikaturer", Martin Fridrich Arendt (1773-1823), der som sendt fra de højere magter pludselig stod i Oehlenschlägers stue på et tidspunkt, hvor digteren netop havde behov for at få en dybere indsigt i de islandske sagaer.

Oehlenschläger skildrede ham „som en en antikvar af første skuffe. Alt, hvad der levede, blomstrede, trivedes, virkede kraftigt i samfun-

\footnotetext{
'Jørgen Jensen: Thomsens Museum. Historien om Nationalmuseet, 1992, s. 107.

${ }^{2}$ Vilh. Andersen: Guldhornene, 1896, s. 80.

${ }^{3}$ Oehlenschlägers Levnet, fortalt af ham selv, 1830-1831, 1-2, bd. 1, s. 195-198.
} 


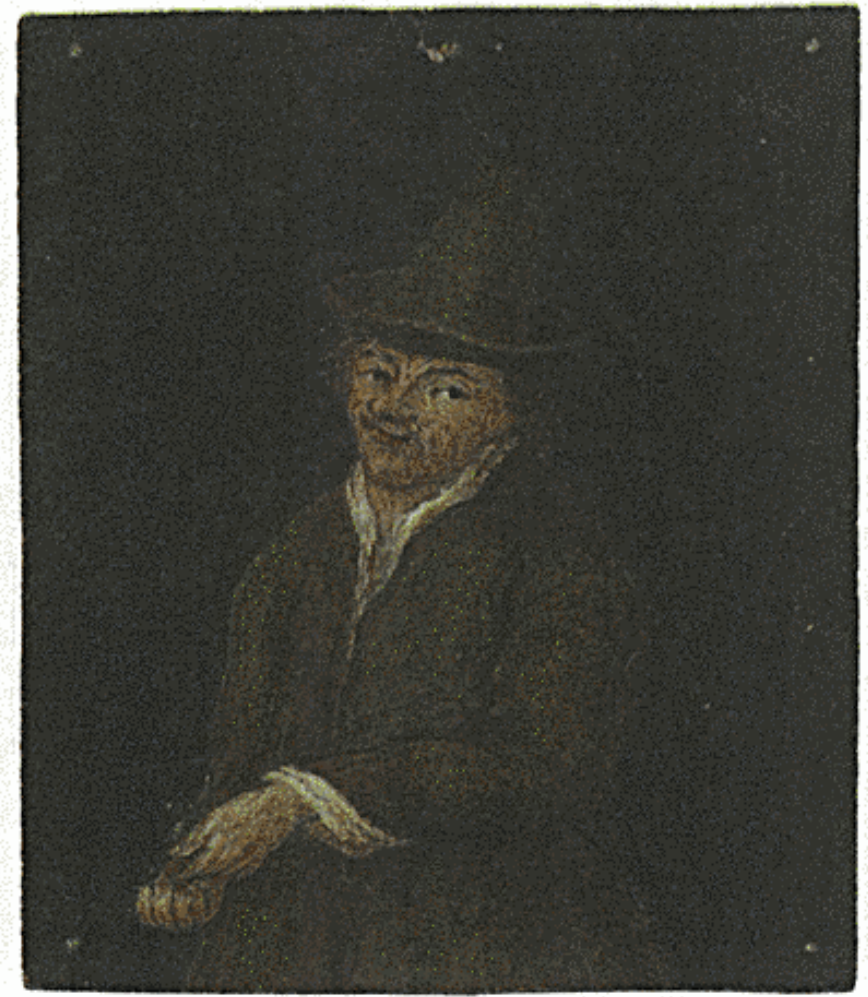

Martin Fridrich Arendt (1773-1823). Akvarel af Jeppe Pedersen Staun (1747-1826). Den er lagt ind i et stykke blåt papir, hvorpå $\mathrm{P}$. Thorsen har skrevet "Arendt blev (af Staun) malet på Endrupholm med en kartoffel $\mathrm{i}$ hånden, det er vist. - Ved at efterspørge derom er indlagte sendt mig fra frøken Anna Teilman som mulig A. - 27/2 56 viste jeg Werl(auff) og Thomsen det. De sagde ikke, at det ikke kunne vare A., men kun at det lignede ham ikke." (NkS. Additamenta $624 \mathrm{c}$, optegnelser om Arendt).

det, foragtede han. Kun de henmuldnede levninger, kun de halv, eller aldeles forsvundne sprogs dunkle sang elskede han. Hele Europa betragtede han som en stor studerestue, hvor han undertiden måtte gå noget langt for at hente citater“. Det morede digteren at vove sig "med antikvaren i den hedenske oldtids mørke. Ligesom Aladdin med Nourredin i den underjordiske hule efter den forsvundne lampe". Vilhelm Andersen er i sine åndfulde værker om Guldhornene og Adam Oehlenschläger ikke i tvivl om, at Arendt var repræsentanten for dem, der higede og søgte i gamle bøger, i de oplukte høje og muldne volde uden at have den fjerneste anelse om oldtidens poesi. Det var formentligt også Arendt, som fortalte digteren om den underlige måde, de to guldhorn var fundet på, det ene 100 år efter det andet og på samme sted, og om deres arkæologiske betydning. ${ }^{4}$

4 Guldhornene, 1896, s. 28, og Adam Oehlenschläger 1899, bd. 1. s. 83 ff. 
Næste gang Oehlenschläger havde besøg af Arendt var i Paris i 1807, hvor oldforskeren både ved sin påklædning og sin adfærd bekræftede det indtryk, digteren tidligere havde fảet af ham. Arendts respektløse tale om kongen gjorde imidlertid Oehlenschläger så gram i hu, at han bad ham forsvinde, ellers ville han kaste ham ned ad trappen, og som digteren tørt bemarker, Arendt ville vare faldet dybt, da han boede i 7. stokværk i hotel Quinze-Vingts. ${ }^{5}$

Den tredje og sidste gang, Oehlenschläger og Arendt krydsede spor, var to år senere i Firenze. Her så Oehlenschläger sammen med vennerne arkæologen P. O. Brøndsted og filologen G. Koes på et gadehjørne „den lille og slet klaedte mand med svulmende kjolelommer .. med den spidse næse i vejret, ligesom en høne, der drikker". De tre venner skyndte sig forbi Arendt uden at give sig til kende eller hilse på ham. ${ }^{6}$ - Mange år senere benyttede Oehlenschläger ham som model til oldforskeren Strauss i dramaet „De ilalienske rovere“, som i 1835 opførtes fem gange på Det kgl. teater. ${ }^{7}$

Eftertidens kendskab til Arendt skyldes ikke, at han efterlod sig en større skriftlig produktion. Tværtimod. Han publicerede kun meget få og små artikler, hvis indhold næepe har bragt oldtidsforskningen fremad. Han foretrak at meddele sin viden mundtligt, ofte under timelange besøg. Han var bestandig på rejse, havde ingen fast bopæl, og ejede ikke andet end, hvad han stod og gik $\mathrm{i}$. Hans påklæedning var besynderlig; han gik klædt i en lurvet lang overfrakke, hvis lommer var fyldt til mere end bristepunktet med papirer, og han havde altid blyant, lineal og passer med sig til brug ved studiet af fortidens levn.

Arendt kom vidt omkring på sine rejser, og han akkumulerede en omfattende viden om en række antikvariske emner. Det besynderlige udseende og hele hans fremtraden til trods blev han verdsat af samtidens oldgranskere, der anså ham for en mand, hvis læsning af runer og andre indskrifter, man burde lytte til. Forbløffende mange har i breve, dagbøger og artikler omtalt Arendt, og i datidens antikvariske litteratur er talrige henvisninger til Arendt. Særlig interesse knytter sig til nogle beskedne papirer, der findes i Det Kgl. Biblioteks håndskriftsamling. ${ }^{8}$ Det er notater, som indeholder dels skildringer af

\footnotetext{
${ }^{5}$ Oehlenschläger (note 3), bd. 2, s. 136-137.

${ }^{6}$ Oehlenschläger (note 3), bd. 2, s. 261.

${ }^{7}$ Oehlenschläger: Erindringer, 1850-1851, bd. 2, s. 128. F.L. Liebenberg: Bidrag til den Oehlenschlagerske Lileraturs Historie, 1868, s. 346-347.

${ }^{8}$ KB. NkS. Additamenta 624 c. Optegnelser om oldforskeren Arendt.
} 
Arendts person, dels erindringer, flere steder direkte citater fra, hvad han fortalte i $1814 \mathrm{og} 1815$ til brødrene Tøger Teilmann til Endrupholm og Charles Teilmann til Kærgaard. Det er usikkert, hvornår disse oplysninger blev nedskrevet, men det fremgår, dels at Charles Teilmann i januar 1844 sendte dem til runeforskeren P.G. Thorsen, dels i 1851 mundtligt gav Thorsen en rakke supplerende oplysninger om Arendt. ${ }^{9}$

\section{Botanicus Martin Fridrich Arendt}

Arendt var født 22. februar 1773 i Altona, hvor han, i moden alder må det siges, afsluttede gymnasiet $\mathrm{i}$ april 1794. Hans hu stod til naturhistorie, især plantekundskaben, og samme år begyndte han at studere botanik og andre naturhistoriske fag, herunder også medicin, ved Universitet i Göttingen.

En helt almindelig student har han næppe varet. Han havde rejseblod $\mathrm{i}$ årene. Allerede inden udgangen af 1794 begav han sig til fods på en studietur rundt $\mathrm{i}$ Tyskland, Østrig, Frankrig og Italien og vendte først i slutningen af 1796 tilbage til Altona.

I januar 1797 indfandt Arendt sig i København, hvor han på grev Chr. D. Rewentlows anbefaling blev ansat som overkomplet elev ved den den botaniske have på Charlottenborg. ${ }^{10}$ Allerede i marts indsendte han en ansøgning til Fonden ad usus publicos om støtte til en rejse til det nordlige Norge med henblik på at indsamle levende planter eller frø til den botaniske have, og den 19. maj bevilgedes han 300 rdl."

Han blev imidlertid ikke tilsmilet af lykken på farden. Allerede begyndelsen tegnede dårligt. Han drog af sted den 1. juni, men nåede først til Nordnorge 12 uger senere i midten af august. Da måtte han erkende, at sommeren gik så meget på hæld, at det ville være formålsløst at iværksætte grundige botaniske studier i marken. Han returnerede derfor til fødebyen, Altona, og anmodede i september om tilladelse og støtte til at fortsætte sine studier det følgende år, hvad han også fik. I sommeren $1798 \mathrm{kom}$ der da endelig gang i hans berejsning af Nordnorge og Finmarken. Men vanskelighederne tårnede sig op.

Klimaet var umildt, transportmulighederne elendige; der var ingen

${ }^{9}$ Erik Moltke har i en artikel om Arendt, Aro og Eje, 1957, s. 70-95, gengivet uddrag af de Teilmannske erindringer.

${ }^{t 0}$ P.E. Müllers nekrolog, Dansk Litteratur-Tidende 1824, s. 309 ff.

"Fonden ad usus publicos 1765-1800, 1897, 1, s. 186. 
veje, og det var stort set kun muligt at komme fra sted til sted med båd, - naturen med de stejle klipper, udstrakte moradser og ufremkommeligt terræen vanskeliggjorde også systematisk indsamling af planter. Et alvorligt problem var, at den periode, hvor han kunne arbejde i felten, var så kort. Den arktiske hektiske sommer, hvor alle planter vældede frem på én gang, for snart efter at forsvinde, gjorde det til en uoverkommelig opgave at foretage en tilfredsstillende indsamling af planter. Midnatssolen blev hans fjende. De få månederne, hvor det var lyst om dagen, var dagene lange, altfor lange, og varmen uudholdelig, samtidig med at millioner af blodtørstige myg jagtede den botaniske vandrer. Endelig havde Arendt heller ikke fået den hjælp og støtte fra den stedlige befolkning, hverken fra embedsmænd eller private, som han burde have haft; det kneb endog med at få udbetalt de penge, som var anvist fra regeringen i København. ${ }^{12}$

Resultatet af rejsen blev mere end magert, og direktøren for den botaniske have i København var absolut ikke tilfreds med det beskedne sortiment af planter og frø, som Arendt afleverede. Men uanset, at udfaldet af rejsen ikke opfyldte de forventninger, man havde gjort sig, anbefalede direktionen for Fonden ad usus publicos, at der blev udbetalt et gratiale til Arendt, hvad han også fik, da det ikke kunne nægtes, at han havde udstået mange besværligheder under de nordlige himmelstrøg. ${ }^{13}$

\section{Den vandrende antikvar Arendt}

Hvornår Arendt blev fanget ind af antikvariske sysler, er ikke helt klart; allerede under sit første ophold i København vendte han blikket mod fortiden. „I skingrende frost stod han hele timer på Universitetsbiblioteket foran skabene, der gemte de arnamagnæanske samlinger, for at bese det ene håndskrift efter det andet. Kammerherre [P.F.] Suhm har fortalt, at Arendt var kommet til ham, for at udbede sig litterer vejledning til at studere Nordens oldsager, og at han med forundring

12 Rigsarkivet. Fonden ad usus publicos. Kongelige resolutioner 1798-1799, nr. 8. Arendts redegørelse for sin rejse, dat. januar 1799, Bilag litr. B, Die Schwierigkeiten einer nordischen, vorzüglich botanischen Reise.

${ }^{13}$ Ibidem. - Bilag litr. A, Skrivelse af 1. marts 1799 fra professor E. Wiborg til direktionen for Fonden ad usus publicos. - Forestilling af 12 . marts 1799 fra direktorene, E.H. Schimmelmann og Chr. D. Rewentlou. Kgl. resolution af 27 marts 1799 om at udbetale et gratiale på $200 \mathrm{rdl}$. én gang for alle til botanicus Arendt. 
havde hørt, at det unge menneske havde læst alle de værker, han navnte ham".14

Selvom Arendt oplevede mange genvordigheder på sin botaniske rejse til dobbeltmonarkiets nordlige egne, havde han ikke mistet lysten til at komme derop igen. I 1799 begav han sig afsted, og dennegang var hans formål ikke primært at studere botanik, men at søge efter de svage spor af minder fra oldtiden, runemindesmærker, gravhøje, stensætninger, kirker, middelalderlige dokumenter og mønter. Indtil 1806 fortsatte han sine antikvariske vandringer i Norge, dog med enkelte afstikkere til Danmark og Sverige.

Såvidt man kan følge Arendt, var han ikke i Norge i 1800, hvor han formentlig har veret i København, og det må have været under dette ophold i hovedstaden, at han dukkede op hos Oehlenschläger. Fra efteråret 1801 var han tilbage i Norge, og vinteren 1801-1802 tilbragte han i Christiania, hvor han naturligvis fik indpas hos en af Norges rigeste og mest indflydelsesrige personer, mæcenen og grandseigneuren Bernt Anker, hos hvem sågodt som alle udlændinge blev bedt som gæster, og hvis righoldige og værdifulde bogsamling var åben for enhver. Den næste vinter tilbragte Arendt i Finmarken.

I 1804 var Arendt i Jylland, hvor han første gang læste og tolkede runeindskrifterne i Jelling. ${ }^{15}$ I december 1805 kom han til overhofintendent Per Tham på herregården Dagnäs i Vestergötland. Her ordnede og katalogiserede han Thams bibliotek; de første måneder af 1806 tilbragte han i Stockholm, hvor han bl.a. blev en velset gæst hos en af Per Thams bedste venner, billedhuggeren J.T. Sergel, der satte pris på Arendts selvstaendige vaesen og var ked af det, da han drog til Norge. ${ }^{16}$ Sidst på året var Arendt $\mathrm{i}$ København, hvor han havde kontakt med flere oldgranskere, bl.a. Laurits S. Vedel Simonsen, som Arendt viste, hvordan man ved at legge et tyndt stykke papir over runeindskrifterne, kunne tage aftryk af dem. ${ }^{17}$ Arendt fors $\varnothing$ gte på dette tidspunkt at få ansættelse ved den arnamagnæanske kommission, men uden held, da han blev uvenner med eforerne. ${ }^{18}$

${ }^{4}$ Frederik Thaarup, Fedrenelandsk Nekrolog, 1835-1844, 1845, s. 166.

${ }^{15}$ Finn Magnussen: Optegnelser på en rejse fra København over Sanderumgaard til Jellinge .. sommeren 1820, Magazin for Reiseiagttagelser, 1823, bd. 3, s. 47.

${ }^{16}$ Harald Schiller: En originell herre. Per Tham till Dagnäs. Den siste Rudbeckianer, 1930 , s. 123,136 og 184 .

${ }^{17}$ Vedel-Simonsens dagbøger, 6. januar 1807, KB. NkS. 4608. Victor Hermansens samlinger vedr. dansk arkaologi, kaps. 8 ,

${ }^{1 *}$ P.E. Müller (note 10). 
En meget kortfattet skildring af sine rejser i Skandinavien publicerede Arendt i Magazin encyclopédique $1808 .{ }^{19}$ Her fremhæevede han flere gange den gxstfrihed, han havde nydt i Norge, også i den nordlige del. Disse udsagn lader sig ikke umiddelbart forene med, hvad han skrev om den nordnorske befolknings holdning til ham i den beretning, han havde indsendt til Fonden ad usus publicos om sine lidet vellykkede botaniske undersøgelser i 1797 og 1798 .

Historikeren Frederik Thaarup, der var foged i Solør nord for Oslo, lærte Arendt at kende i vinteren 1803-1804, „da han kom ikke vandrende, men kørende til mig for at klage over skydsen, modtoges som gæst, fandt behag i min temmelig store bogsamling, og under nogen tids ophold viste sig, som flere steder, hvor han kom, utålelig. Han var kyniker af høj grad, var uartig mod det andet køn, skumlede over de hæderligste personer, og overhovedet i sin hele færd, var som overalt hvor han kom, en byrdefuld gæest, som man vanskeligen kunne bære over med. .. Han gjorde denne rejse med såre liden omkostning, idet han indkvarterede sig hos præster og bønder. Mærkede han, at hans ophold faldt besværligt bekymrede han sig ikke derom, men blev så længe det lystede ham selv. Engang måtte en præst for at blive ham kvit med magt lade ham bringe i et fartøj og sætte over fjorden. En anden gik lempeligere tilværks; han lod midt om vinteren åbningen af hans kakkelovnsrør mure til, og således fik han ham ved røg gjort ked af sit ophold". ${ }^{20}$

Breve fra norske venner til Rasmus Nyerup giver til overmål en skildring af Arendts højst utraditionelle adfærd, når han aflagde besøg hos dem. Ingen var i tvivl om hans fabelagtige hukommelse og omfattende viden både om naturvidenskabelige og antikvariske emner, som han diverterede med i timelange enetaler. Fra tidligt om eftermiddagen til langt ud på aftenen førte Arendt tilhøreren „omkring fra Nord til Syd, Øst og Vest, uden at [man] kunne få et øjebliks pusterum eller et ord indført", og efterlod tilhøreren så fortumlet, at han ikke vidste, hvor han befandt sig. ${ }^{21}$ En anden nordmand, J.C. Bjerg på Gulligård

\footnotetext{
${ }^{19}$ Precis des Voyages et des Traveaux pour l'Antiquité, la Philologie et la Literature scandinave, entrepris en Norvège et en Suéde, depuis 1797 jusqu'a 1806, Magazin encyclopédique 1808, tome VI, pag. 95-99.

${ }^{20}$ Thaarup (note 14).

${ }^{2 t}$ N. Schythe til R. Nyerup, Grimstad, den 28. september 1805. Udvalg af Breve, hovedsagelige fra bekjendle Norlmand til Professor Nyerup, udg. af Ludvig Daae, Chria. 1861, s. $82 \mathrm{ff}$.
} 
ved Tønsberg, karakteriserede Arendt som „en agte cynicus eller på dansk et svin“, der talte om personer, som han ikke var vardig at nævne, og om ting og indretninger i staten, som ikke vedkom ham som „den lærde landstryger“, han var. Arendt forsøgte åbenbart også at score points hos sine norske værter ved at udtale sig „meget foragteligt om de danske - ventelig forhåbende derved at insinuere sig ligesom jeg [J.C. Bjerg] formoder, han taler om de norske i Danmark". ${ }^{22}$

I 1807 drog Arendt til Rostock, hvor han opsøgte orientalisten, professor O.G. Tychsen for at få hjæelp til at beskrive Thams kufiske mønter. Derfra vandrede han til Paris, og her blev han godt modtaget af professor A. L. Millin. Sin vane tro kunne Arendt ikke andet end vare grov og uforskammet over for den berømte arkæolog og historiker. „Han forekastede ham uvidenhed. Man kan ikke tanke sig to større kontraster! Millin rig, fornem, beboer af et dejligt hotel, hvortil alle lærde havde fri adgang visse timer om ugen, og kunne i prægtige værelser læse alle nye bøger og journaler; - og Arendt i en grov frakke af blåt filt, de lange hår under kraven og alle lommerne svulmende af papirer som pocher eller fiskebensskørter".".s

Det var i det af Millin udgivne magasin, at Arendts lille artikel om hans antikvariske studier i Skandinavien blev trykt, og det var også her han publicerede en notits om Thams kufiske mønter. ${ }^{24}$ Millin har formodentlig også haft indflydelse på, at Arendt i juni 1809 holdt et foredrag om „Les plateaux circulaire construits de cailloux qui se trouvent au Nord de l'Europe" for medlemmerne af det keltiske Akademi. Her prasenterede Arendt sig som ,antiquaire, philologien et botaniste Danois“. ${ }^{25}$

En aften i 1809, hvor en kreds af videnskabsmæend, særlig oldforskere var samlede hos Millin, faldt talen på den berømte marmorløve i Venedig, og det diskuteredes, hvorvidt indskriften virkelig var skrevet med runer. Arendt tog straks sin hat og vandrede af sted til Venedig, hvor han undersøgte de indhuggede tegn på løven så nøjagtig som muligt. Derefter vendte han tilbage til Paris og indfandt sig, som om

\footnotetext{
${ }^{22}$ Udvalg af Breve (note 21), s. 56. J.C. Bjerg til R.Nyerup den 31. oktober 1806.

${ }^{3}$ Oehlenschläger (note 3 ).

${ }^{24}$ Magazin Encyclopédique, 1808, tome VI, s. 311-313. - „Notice sur d'une suite de médailles coufiques".

${ }^{2}$ Manuskriptet til foredraget ligger blandt Arendts papirer, Nationalmuseets afdeling for middelalder, arkivkasse 43.
} 
han lige havde forladt stuen, hos Millin på den sxdvanlige aften, hvor Millin plejede at samle kredsen af videnskabsmænd og meddelte, at det var runer, men de var så udslidte, at ingen ville være i stand til at lase dem. ${ }^{26}$

Under opholdet i Paris fik Arendt lejlighed til beskrive nogle af Napoleons mønter. Senere blev han imidlertid så vred på kejseren, at han ikke kunne tilgive sig selv, at han på en måde have bidraget til „den mands hæder, som han foragtede ". ${ }^{27}$ - Det var også i Paris, at han mistede sit ene øje, da han lå syg af gigt og ikke fik den rigtige pleje og behandling."

\section{Das gelehrle Ungeheur}

Arendt forlod Paris i 1809 og rejste via Bruxelles til Holsten og Slesvig, hvor landgrev Carl af Hessen gav ham en anbefaling til en antikvarisk rejse $\mathrm{i}$ hertugdømmerne, som han foretog $\mathrm{i} 1810 \mathrm{og} 1811$, idet han dog tilbragte vinteren i København. ${ }^{29}$

Hans rejse eller rettere sagt hans huseren i Holsten er skildret af domherre Meyer ${ }^{30}$ Ganske vist nævner Meyer ikke direkte Arendt ved navn, men der er ingen tvivl om, hvem der skjuler sig bag karakteristikken af "das gelehrte Ungeheur“. Det er ingen flatterende beskrivelse. Overalt, hvor han frem, påberåbte han sig sine anbefalelsesskrivelser, og nærmest voldgæstede embedsmænd, præster og bønder, trængte sig ind i deres hjem, strakte sig på sofaen og gjorde krav på såvel forplejning som overnatning. Han kastede sig ubehersket over mad og drikke ved bordet og beklagede sig bagefter over tilberedelsen, men kom takkende tilbage et par dage senere. Han granskede værtsfolkenes biblioteker, tog imidlertid aldrig notater af, hvad han læste, idet han berømmede sig af sin hukommelse, og hævdede, at han aldrig glemte, hvad han havde læst, og han huskede titlen på alle bøger og tidsskrifter, han havde set og endog kunne erindre sidetal. Han talte ufordelagtigt om alt og alle, endog statens ledende mænd.

\footnotetext{
${ }^{26}$ Ludvig Wimmer: Om undersogelse og tolkning af vore runeindskrifter; $1895, \mathrm{~s} .1$.

${ }^{27} \mathrm{NkS}$. Additamenta (note 8 ).

2s Thaarup (note 14).

${ }^{2}$ E.C. Werlauff skriver den 6. november 1810 til Vedel Simonsen, at Arendt stadig er i byen. Fra Fyens Fortid, 1916, 1, s. 153.

${ }^{3}$ Darstellungen aus Nord=Deutschland, 1816, s. $257 \mathrm{ff}$.
} 


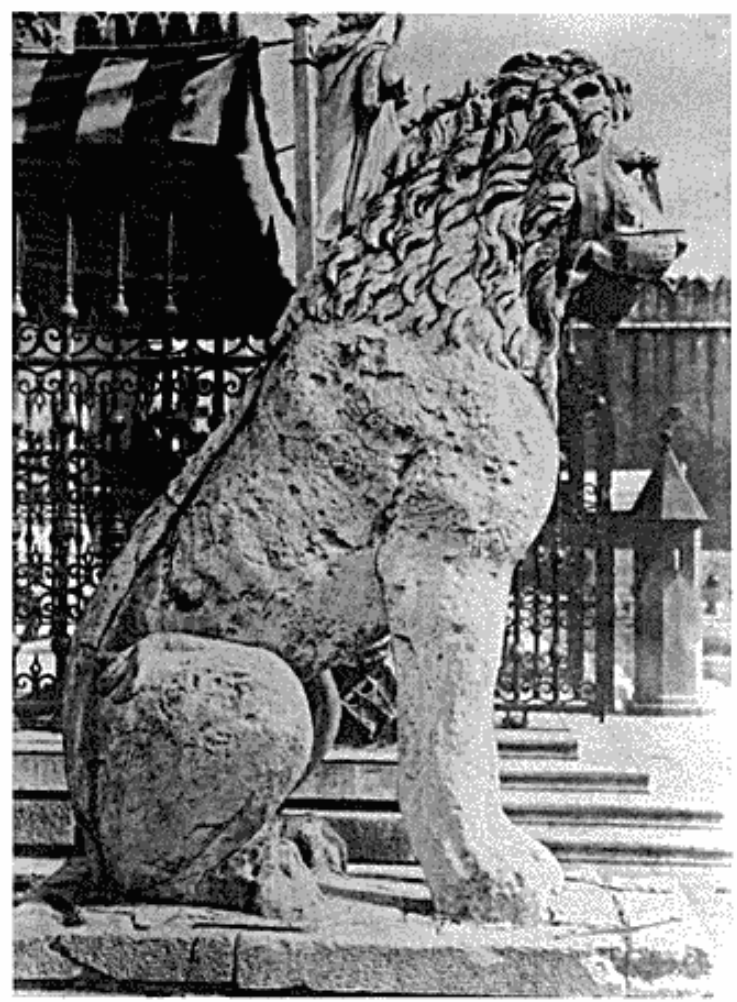

Marmorløve. Den stod ved havnen i Pireus, men efter at venetianerne i 1687 havde indtaget Athen, førtes den til Venedig, hvor den blev opstillet ved Arsenalet. På dens sider er svage spor af en runeindskrift. Mange nuneforskere har beskaftiget sig med indskriften, med Arendt var også her den mest nøgterne, da han erklarede, at tegnene var for nedslidte, til at man kunne lase dem. (Foto ca. $1854 \mathrm{i}$ Nationalmuseet.).

Hans besøg havde imidlertid en ikke ringe underholdende vaerdi, da han kunne fortælle mange interessante ting!

I forbindelse med sine antikvariske rejser i Holsten og Slesvig var Arendt i 1811 for anden gang i Jelling for at aftegne runeindskrifterne. I november samme år var han atter i Norge, hvor han bl.a. hjemsøgte J.C. Bjerg på Gulligaard og opførte sig præcis lige så ubehageligt som, da han var der i 1806. Arendt havde fortsat „et modbydeligt vasen“, og selv om Bjerg havde den dybeste respekt for hans lærdom, så ønskede han dog ikke at se ham oftere. ${ }^{31}$

Derfra vendte han tilbage til København og overdrog i 1812 en række papirer til kongens håndbibliotek, idet han dog udtrykkelig frabad sig, at oldforskere i København måtte få adgang til hans samlinger, sålænge han levede. - Blandt hans papirer, som nu findes i Nationalmuseets arkiv, er der et koncept til ansøgning til kongen om at få un-

\footnotetext{
${ }^{31}$ Udvalg af breve (note 21), s. 58.
} 
derstøttelse til en antikvarisk rejse til Norge og om at blive anbefalet til „Selskabet for Norges vel“. ${ }^{32}$ Konceptet er ikke dateret, men af dets indhold fremgår, at det er skrevet efter hans rejser i Hertugdømmerne, muligvis 1812. Det er tvivlsomt, om Arendt fik afsendt en ansøgning. Der er i hvert fald intet, der peger i retning af, at han fik kongelig understøttelse til sit projekt. Der var trods alt græenser for den royale generøsitet.

I 1813 dukkede han meget forhutlet op i Ålborg, hvor byens borgere tog sig af ham og gav ham mad og tøj samt penge, så han kunne rejse til Norge. ${ }^{33}$ De næste år strejfede han omkring i Norge og Sverige, hvor han fortsat var i stand til at finde formående velyndere, som altid hos the upper ten, bl.a. den russiske gesandt, general J.P. van Suchtelen og grev J.G. de la Gardie. ${ }^{34}$

Også hos jyske godsejere var han en velkommen gast. I $1814 \mathrm{og}$ 1815 var han i Danmark, hvor han formentlig mest holdt til hos den oven for omtalte hofjegermester Tøger Teilmann på Endrupholm i det sydvestlige Jylland; sidst på året 1815 var runestenene i Brkke og Læborg genstand for hans nidkære granskning. ${ }^{35}$ Ved sommerens begyndelse i 1816 var han igen i Ålborg, hvorfra han begav sig til Norge, og her nød han bl.a. gastfrihed hos den rige historisk interesserede jernverksejer Jacob Aall (1773-1814) på Nes. ${ }^{36}$ Senere samme år var han i Stockholm og besøgte atter Per Tham på Dagnäs, men rejste tilbage til Norge allerede om efteråret ${ }^{37} \mathrm{I} 1818$ udgav han i Linköping et folieblad med runealfabeter, og i november 1819 passerede han København på vej til Tyskland, og her udgav en lille fortegnelse over de vendiske gudebilleder i Neu-Strelitz. ${ }^{38}$

Fra Nordtyskland vandrede han til Italien. Opholdet syd for alperne bød imidlertid ikke på lutter gode oplevelser. Vel fik Arendt tilladelse til at fæerdes i Vatikanets bibliotek, men hans interesse for dokumenterne med de nordiske bogstaver vakte bibliotekarens mistanke, og

${ }^{32}$ Nationalmuseets afdeling for middelalder, arkivkasse 43.

${ }^{33}$ Müller (note 10), s. 311.

${ }^{3}$ Bengt Hildebrand: C.J. Thomsen och hans lärde forbindelser $i$ Sverige 1816-1837, 1937, 1. bd. s. 428.

${ }^{s}$ Finn Magnussen: Efterretninger om Mindesmerkerne ved Jelling og de derved $i$ Aarene 1820 og 1821 foretagne Undersogelser m.m., 1823, s. 47 og 58.

${ }^{*}$ Th.H. Erslew: Almindeligt forfatter-lexikon 1814-1840, 1841, s. 21-22.

${ }^{37}$ Schiller (note 16), s. 223.

${ }^{3 *}$ D.L. Lübker \& H. Schröder: Lexikon der Schleswig-Holstein-Lauenburgischen und Eutinischen Schriftsteller von 1796 bis 1828, 1829, s. 23. 
han blev forment adgang til fortsatte studier på stedet. ${ }^{39} \mathrm{Og}$ værre gik det siden. Litteraten F.C. Hillerup mødte Arendt i Rom i vinteren 1820-1821, og kaldte ham „en levende encyklopædi, et omvandrende konversationsleksikon " ${ }^{40}$ Han fortaller, at Arendt talte dansk, akkurat som det blev skrevet, hvad der ofte havde en meget komisk virkning. Han havde et langt hvidt skæg, der næsten nåede ned til brystet, og han var iført en farveløs overkjole med utallige rifter og lapper, og en hat, hvis form det mindste vindpust kunne forandre, samt sandaler, der var fastbundne med sejlgarn, og hans vandringsstav var en stor knortekæp. Men værst af alt, „Arendt manglede finhed i omgangen“. Måske var det hans mærkelige fremtoning, måske var det fordi han gik rundt med besynderlige papirer med runer og islandsk skrift, foruden at han havde nogle penge på sig og havde varet et smut i Spanien, som førte til, at han i Neapel blev anset for at være i ledtog med et hemmeligt politisk selskab (carbonari), og derfor arresteret og indespærret i det for statsforbrydere bestemt fængsel St. Francesco. Ved landsmænds hjælp, ikke mindst fra den danske chargé d'affaire, blev han løsladt, men Arendt havde under fængselsopholdet pådraget sig en varig sygdom. Så satte han atter kursen mod nord, dog med en afstikker til Ungarn, hvor grev Viczay gav ham typerne til det keltiske alfabet, som Arendt derefter altid gik med i en af sine lommer. ${ }^{41}$

I maj 1821 var han i sin fødeby Altona, hvor han meddelte, at han ville rejse endnu i tre år og derefter finde et passede sted for at bearbejde resultaterne af sine undersøgelser og forskninger. ${ }^{42}$

I løbet af foråret $1822 \mathrm{kom}$ han til Danmark, hvor han i høj grad imponerede Johan Bülow på Sanderumgård med sin viden, ikke mindst om monumenterne i Jelling. Arendt må åbenbart have stukket en finger i jorden og vidst, at oldgranskeren Finn Magnussen var højt anskreven hos Bülow, og derfor roste han denne til skyerne. Det varede imidlertid ikke længe, førend Bülow blev klar over, at Arendt var en tvivlsom gast. Under opholdet på Sanderumgård var han blevet lidt for familiær med folkene i køkkenet; Bülow ønskede ikke at se ham igen. $^{43}$

39 NkS. Additamenta (note 17).

${ }^{40}$ Valkyrien, 1832 , bd. 1, s. $124 \mathrm{ff}$.

"Müller (note 10), s. 312.

42 Lübker (note 38), s. 23.

${ }^{45}$ Rigsarkivet. Privatarkiver, nr. 5943. Finn Magnusson. Breve fra Johan Bülow, 1822, 6. april, 15. maj og 26. juni. 
Den 1. maj 1822 meldte Arendt sig hos sekretæren i Oldsagskommissionen Chr. J. Thomsen og havde med ham en samtale, der begyndte kl. $7 \mathrm{om}$ morgenen og endte $\mathrm{kl} .1 \mathrm{om}$ middagen. „Den var af den mest besynderligste og forskelligste natur - numismatisk, runologisk, antikvarisk, politisk, økonomisk, satirisk, blandet med sindrige bemærkninger, spor af sjældne kundskaber, men også med gift, edder og galde. Siger han blot det halve om mig, som han ytrede om andre, han nylig har forladt, står jeg som den største idiot, forfængelige nar og Gud véd hvad"." Arendt benyttede også lejligheden til at give en kritik af Thomsens afbildninger af guldbrakteater, en kritik, som Thomsen indså var berettiget, idet han samtidig måtte erkende, at det var umuligt at leve op til Arendts ideelle fordring; men Thomsen var utilfreds med, at Arendt kun flygtigt havde studeret samlingen af oldsager på Trinitatis kirkeloft.

Sommeren 1822 tilbragte Arendt i København, hvor han boede i en kælder og ernærede sig for 8 skilling om dagen. Her besøgte han byens oldgranskere, bl.a. biskop Friedrich Münter, Finn Magnussen og Børge Thorlacius, hvis hustru han fornærmede groft. E.G. Werlauff trak vejret lettet over, at Arendt ikke havde varet hos ham. ${ }^{45}$ Thomsens ord om, hvor vigtigt det var at se oldsagssamlingen, faldt åbenbart ikke helt på stenet grund. I begyndelsen af oktober måned traf Vedel Simonsen Arendt på Rundetårn, hvor „Thomsen docerede“, og om eftermiddagen var det så Vedel Simonsens tur til at have et otte timers langt besøg af Arendt fra kl. 3 om eftermiddagen til kl. $11 \mathrm{om}$ aftenen; Vedel Simonsen måtte stå skoleret, og det endte med, at han tilbød Arendt $10 \mathrm{rdl}$, som denne afslog at tage imod! ${ }^{46}$

Det var sidste gang, hovedstadens oldgranskere så Arendt. Derefter må han have begivet sig sydpå. Han nåede til Italien, og her blev han $\mathrm{i}$ 1823 fundet død i en landevejsgrøft et par mil fra Venedig.

\section{"Jeg er den larde antikvar Arendt"}

lød svaret til en jysk herremand, der spurgte, hvem han var, og han tilføjede, „dersom De endnu ikke kender mig, røber det, De har haft en forsømt opdragelse“. ${ }^{47}$

"Chr. J. Thomsen til Sven Hylander, 2. maj 1822, Hildebrand (note 34), s. 462.

${ }^{45}$ Fra Fyens Fortid (note 29), s. 193 ff.

${ }^{4} \mathrm{NkS}$. Vedel Simonsens dagboger (note 17), 3. oktober 1823.

${ }^{47}$ Müller (note 10), s. 311. 
Det kunne måske knibe for Arendt at blive godt modtaget overalt, hvor han kom frem. Men der var steder, hvor han var velkommen. Det var i Danmark bl.a. som næunt hos hofjægermester Tøger Teilmann på Endrupholm og broderen Charles Teilmann til Kjærgård. I ovenfor omtalte optegnelser om Arendt er der en beskrivelse af Arendt der var lille af vækst med kun ét øje; han var iklædt lange benklæder, hvid vest og halstørklæde og havde store støvler, hvor bomuldsstrømperne altid skinnede igennem. Når han opholdt sig nogle dage på en herregård, blev han barberet og vaskede selv sit tøj, da han erklærede, at man burde være uafhængig af det svage køn. Han drak aldrig vin eller spiritus. Han fortalte begejstret, klart og tydeligt om alting, og han anså det for mere gavnligt at udtrykke sig mundtligt end på skrift.

Notaterne indeholder udsagn om, hvad Arendt mente om en række antikvariske emner, især runeindskrifter, og de danske oldgranskere fik også et par ord med på vejen. Dem karakteriserede han som „indbildske ukyndige dosmerpander, hvoraf ikke én fatter hvilken vigtighed runeforklaringerne ville vere - med hæderlig undtagelse af $\mathrm{Ny}$ erup“. Ingen af dem havde de omfattende kundskaber og den åndsklarhed og erfaring, som Arendt besad, og han mente, der ville gå 25 år eller måske 50 år, inden de så lyset. Det var Arendts opfattelse, at der ville gå 50 år, inden man ville begynde at forstå ham, men det ville først være om 100 år, at man ville lade ham vederfares retfærdighed. Arendts dom over oldgranskerne $\mathrm{i}$ København var hård:

„Biskop Münter var en dumdristig tyv, der havde stjålet overalt i samlingerne. Man måtte skamme sig ved at være hans landsmand, hans sidste mesterstykke havde varet i Lund, hvor han ligefor professorernes nase kaprede 3 uvurderlige små runemønter, der ikke var mage til i verden, og lod skuffen falde så mønterne rullede bort.

Finn Magnussen var en blære, der indvævede og fordærvede alt ved sin altforstore digtergave, det er sludder og løgn, der fordærver og forvilder alt hans historiske arbejde og bringer folk i det mindste et århundrede tilbage, da ingen nulevende kan holde ham tilbage og stoppe munden på ham.

Bülow Sanderumgård er en forfængelig nar, der ville smigres af de lærde, men vidste ingenting.

Nyerup er en brav mand, som mener det godt, har kundskaber og man kan være bekendt at omgås med ham.

Thim ${ }^{48}$ er uskaterlig for møntkundskab. Han har klar sund forstand

${ }^{4}$ Georg Friedrich Timm (1746-1829), holkleinsmed og kendt møntsamler. 
og megen smag. Har selv studeret sig ind i sit fag, og kender hver mønt med utrolig sikkerhed. - Men hans kundskaber er alene denne gren.

Rafn ${ }^{49}$ er en ren nathue uden kritik og kundskaber, men han har hoved og vedhæengen til at samle, og dumdristighed at tilegne sig som sit eget, hvad andre har udtænkt. [Hertil har Thorsen i margen tilføjet: NB. dette må væere sagt efter 1815].

Brøndsted véd en del, og den græske kunsthistorie kender han endog nøje, men indser ikke dybden af den nordiske oldhistorie, fordi han mangler kundskaber".

Men hvordan så de danske oldgranskere på ham? Svaret er: med forbløffende stor overbærenhed.

Rasmus Nyerup næunte i sine skrifter flere gange Arendt og kaldte ham i 1806 „den lærde oldgransker“ og „en af vor tids mest udmærkede grublere i de nordiske oldsager". Nyerup forstod nødvendigheden af ved selvsyn at gøre sig bekendt med monumenterne ude i landet, og erklærede, ,at vor Arendt har ret, når han påstår, at en antikvar som blot har sin visdom fra bøger, en antikvar som ikke har rejst og selv beset mindesmærkerne fra oldtiden, ikke er en halv skilling værd“. ${ }^{50}$ Nyerup tog imidlertid afstand fra Arendts påstand om, at furerne på Runamo var et „lusus naturae“, et spil af naturen. ${ }^{51}$ Runamo er en flad klippe i Hoby sogn i Blekinge, og dens mærkelige sprækker og revner fremkaldte allerede i middelalderen sagn om, at der her var indhugget runer. Saxo omtaler stedet i Gesta Danorum, og han var ikke i tvivl om, at det var den fra sagnhistorien kendte Harald Hildetand, der lod indskriften hugge i klippen til minde om sin far og Bravallaslaget. Hverken Saxos samtidige eller senere århundreders oldgranskere, der aflagde besøg på stedet, kunne få mening i tegnene. Arendt var ved Runamo flere gange og var den første oldtidsforsker, der erklærede, at det ikke var runer, men naturlige ridser og revner.

Finn Magnussen omtalte Arendts læsning af runeindskrifterne i Jelling, Laborg og Bakke med respekt. Havde Magnussen haft mere tillid til Arendts opfattelse af Runamo, ville han næppe være kommet så galt af sted siden, da han som medlem af den af Videnskabernes Selskab nedsatte kommission sammen med geologen G. Forchhammer,

${ }^{4}$ C.C. Rafn (1795-1864), oldgransker, professor.

${ }^{50}$ Rasmus Nyerup og Søren Abildgaard: Antikvarisk Reise i Aarhus stift 1771-1807, $1808, \mathrm{~s} .14$

${ }^{51}$ Rasmus Nyerup: Historisk-Statistiske skildring om tilstande i Danmark og Norge, bd. 4. 1806, s. 95 og 134 . 


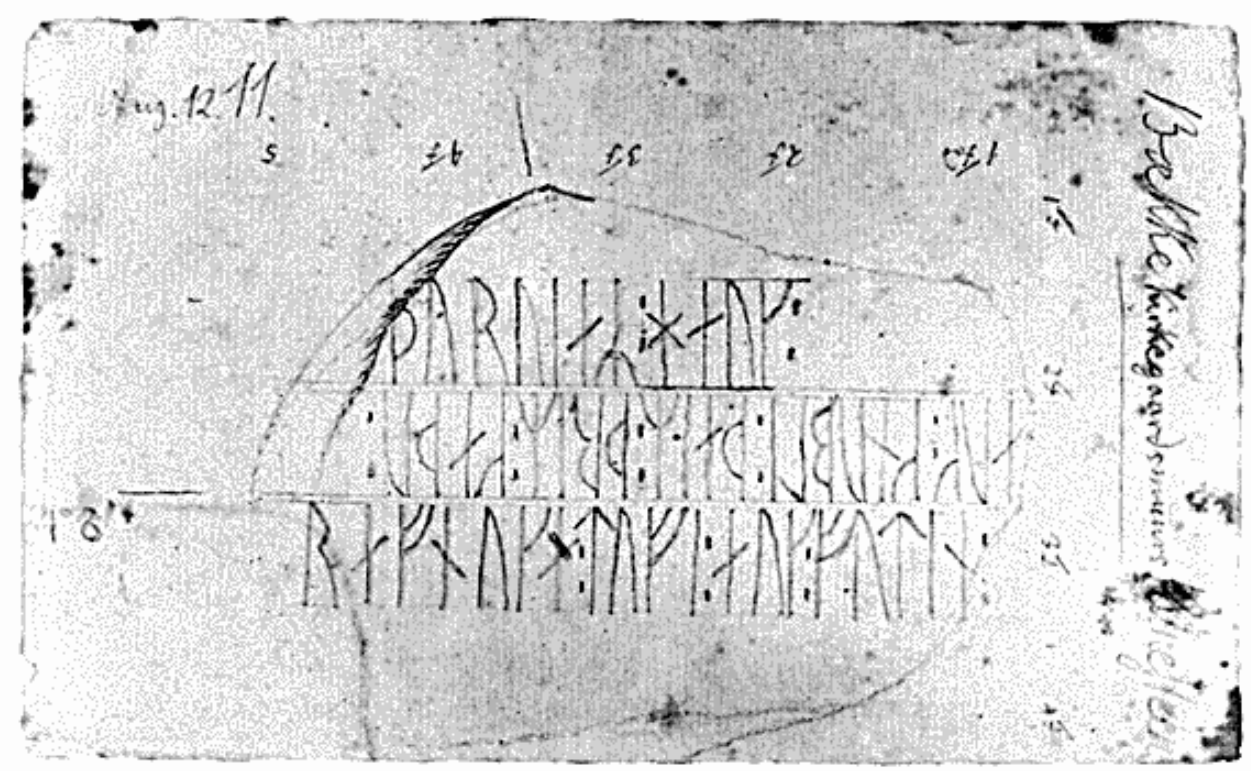

Bakkestenen. Arendts blyantstegning findes på et lille fugtplettet lommebogsblad. Arendt var den første, der i 1811 tegnede denne runesten, der sad i et kirkegårdsdige. (Tegning i Arendts papirer. Foto Nationalmuset).

historikeren og litteraten Chr. Molbech og tegneren C.F. Christensen undersøgte klippen i 1833. Ud fra naturvidenskabelige kriterier afgjorde Forchhammer, hvilke af de mange streger og og ridser i klippen, der skyldtes naturen, og hvilke der var indhuggede af mennesker. Det følgende år, efter at tegningen af indskriften var stukket $\mathrm{i}$ kobber, var Finn Magnussen med udfoldelse af den største læerdom i stand til at læse og tolke den formentlige indskrift - den skulle leses fra højre mod venstre - som varende et oldnordisk stavrimet kvad, hvor Harald Hildetand mænds anråbte guderne om ødelæggelse for Haralds fjender og sejr for ham selv. Magnussens videnskabelige bedrift vakte anerkendelse og berømmelse såvel $\mathrm{i}$ Danmark som i udlandet. Men skuffelserne meldte sig. Svenske naturvidenskabsmænd stillede sig skeptisk, og i 1844 kunne den unge fremadstormende danske arkæolog J.J.A. Worsaae definitivt konstatere, at alle de sprakker og revner, som Magnussen havde tydet som runer, var naturens værk. Præcis som Arendt havde sagt. ${ }^{52}$

${ }^{52}$ Iver Kjaer, Runer og revner i Blekinge og bag voldene. Oldgranskeren Finnur Magnússons berømmelse og nederlag. Guldalderhistorier, 1994, s. $126 \mathrm{fr}$. 
Werlauff misbilligede i allerhøjeste grad Arendts optræeden, men anerkendte hans viden, og det samme gjorde Vedel Simonsen og Chr. J. Thomsen. Også i udlandet blev Arendt respekteret som det fremgår af P.E.Müllers nekrolog. ${ }^{53}$ Selvom Arendt kun i yderst begranset omfang efterlod sin viden om oldtiden i skriftlig form, så havde hans studier trods alt gjort et sådant indtryk, at den franske litterat Xavier Marmier, der i 1837 foretog en studierejse til Danmark, henviste til ham som en af de betydningsfulde oldgranskere i Norden. ${ }^{54}$

\section{Arendt som forsker}

Der er ikke tvivl om, at Arendt er den mest besynderlige oldgransker, der har virket i Danmark. Han var bestandig på rejse og foretog sine antikvariske undersøgelser på de steder, hvor mindesmærkerne var. Han var født i Altona, og tysk var hans modersmål, men han skrev og talte dansk. For ham strakte monarkiet sig fra Altona til Nordkap, og han betragtede hele Europa som et antikvarisk kabinet, mellem hvis fjerntliggende sjaldenheder han syslede som opsynsmand, og hvor han undertiden måtte gå langt for at hente citaterne. Sin viden formidlede han ikke skriftligt, men delte mundtligt gavmildt ud af den til samtidens oldtidsforskere i ind- og udland, og til dem, der måtte have lyst til høre på ham, ja i flere tilfælde vel også selvom det kunne skorte på interessen hos tilhørerne. - Han stolede ikke på nogen og bar derfor altid sine papirer og tegninger på sig. Når byrden blev ham for tung, gemte han en pakke i et eller andet stengærde, men fortalte ingen, nøjagtig hvor han nedlagde sin viden.

Arendt betragtede sin antikvariske videnskab som så privilegeret, at han havde krav på gratis logi og forplejning overalt, hvor han kom frem. Han må have mødt skuffelser undervejs. Hans påklædning og bizarre fremtraeden gjorde indtryk, ikke altid lige positivt, og det bidrog vel også til, at mange af de skildringer, eftertiden har af ham, af og til kan have et anekdotisk præg. Uanset sin mærkværdige fremtoning lykkedes det ham at skaffe formående velyndere, selvom han var alt andet end smigrende i sin adfærd over for dem, ja undertiden mere end grov. Hos de historisk og antikvarisk interesserede godsejere eller rigmænd kunne han nyttiggøre sig ved at ordne deres samlinger af mønter og sørge for, at deres biblioteker blev bragt á jour.

\footnotetext{
${ }^{53} \mathrm{Jfr}$. note 10.

st Revue de deux Mondes, 1837, s. 797.
} 
Hans store viden kom kun i begrænset omfang forskningen til gode. Det er som runelæser og tegner, han fik betydning. Arendt gengav runerne med langt større nøjagtighed, end det tidligere var gjort, og hans læsning var underbygget af, at han i modsætning til sine forgængere i runefaget kunne oldislandsk. Han var en fin og skarp iagttager, og det store fremskridt $\mathrm{i}$ hans tegninger $\mathrm{er}$, at han slår ned på det væsentlige i hvert tegn, og søger at fastholde runernes individualitet. Arendt var den første, måske den eneste runolog, der forenede tegneren og sprogforskeren i én person. ${ }^{55}$ Sine omfattende rejser til trods nåede Arendt ikke frem til en sandsynlig opfattelse af runernes oprindelse, og han skrev aldrig noget samlet om runer. Han var perfektionist og mente, at runebogstaverne først rigtig kunne forklares, når han havde været i Finland, Island og Spanien, og at det desuden krævede kendskab til de indiske sprog. De udsagn og vurderinger af runeindskrifter, som Arendt havde meddelt Teilmann, synes ikke at pege i retning af, at han som runeforsker ville have efterladt sig blivende spor. Dertil var hans ideer om runernes indhugning i stenene for fantastiske.

Det var heurestikken, der var drivkraften $i$ hans antikvariske sysselsætning, dvs. opsøgningen af mindesmærkerne, hvor de var, og nøjagtig læesning af indskrifterne. Ofte måtte han besøge stederne flere gange. Han ønskede alting undersøgt tilbunds, førend han skriftligt gav noget fra sig, $o g$ han stillede store krav både til sig selv og til andre forskere. Ud fra den viden, vi har om ham og den måde, han gemte sine papirer og notater på, forekommer det usandsynligt, at han nogensinde ville blive i stand til at bearbejde sine undersøgelser og forskningsresultater og bringe dem i en større samlet fremstilling.

Arendts liv og levned er højst ejendommeligt. For vor tid kan det forekomme sxlsomt, at en person som han var i stand til at vinde indpas hos så mange af datidens fornemste folk. Det er tvivlsomt, at en lignende original ville kunne gebærde sig på samme måde i dagens Danmark. Ville han være velkommen og blive taget seriøst i de højeste sociale lag i vor tid? Umiddelbart er svaret nej. Ligner han H.C. Andersen lidt?

Der er ingen tvivl om, at Arendt besad en vis charme, og at hans besøg rundt omkring havde underholdende vardi. Det har været morsomt at lytte til denne intellektuelle og velorienterede omstrejfer, når han fornøjeligt, formentlig også maliciøst, fortalte om kendte folk og

\footnotetext{
${ }^{35}$ Erik Moltke, bl.a. Jon Skonvig og de andre nunetegnere, 1958, 2, s. 212 ff.
} 
naboer, selvom mange af hans værter ved nærmere eftertanke blev klar over, at det ved Arendts gæsteoptræden næste sted, ville være dem, der var genstand for hans alt andet end skånsomme omtale.

Arendt levede i en tid, hvor der var mere rum for sære eksistenser, end der er idag. Han var ikke uborgerlig i en borgerlig tid. Han var en særling, og samtiden havde overskud til også at acceptere folk som ham. Det er vanskeligt at forestille sig Arendt vandrende omkring i andre tidsaldre end i den sidste periode af den oplyste enevalde i den dansk-norske helstat.

\section{SUMMARY}

KIRSTEN ELISABETH-HØGSBRO: A first-rate antiquarian Martin Frederik Arendt 17731823

Martin Frederik Arendt was born in Altona in 1773 and died in 1823, in a roadside ditch 2 miles from Venice. He is the most remarkable antiquarian who has lived in Denmark. Throughout his life he travelled, and wandered on foot not only all through Denmark and Norway, but also through large parts of the rest of Europe, where he carried out antiquarian studies in the places where the monuments were. In his own time, he was known as "the wandering antiquarian", and he was a well-known figure, because of both his erudition and his bizarre appearance and way of life. His main interest was runic monuments, and it is as a rune reader that he made his mark. About 1800 , Adam Oehlenschläger made his acquaintance, and there is little doubt that he had Arendt in his mind when in "Guldhornene" (1803), he wrote about those who "have a longing and search in old books". The Danish antiquarians of the time had an ambivalent attitude to Arendt, who seemed fascinating and repellent at the same time, but they had respect for his knowledge. In spite of his dishevelled appearance and his frequently very rude behaviour, he was able to find influential patrons in the highest stratum of society at home and abroad. He left only a few, short, written works; he primarily imparted his extensive knowledge orally, and he did this absorbingly, usually peppered with amusing, not to say malicious, remarks about everything and everyone. His setting was the final period of the enlightened absolute monarchy in the DanishNorwegian united state, and he was accepted as the eccentric he was. That would be unlikely in our time. 